\title{
HII TRES IVRE QVIDEM DOMINVS SVNT VNVS ET IDEM El tímpano de Jaca y la escenificación de la ortodoxia
}

\author{
Francisco de Asís García GarcíA ${ }^{1}$ \\ Departamento de Historia del Arte I (Medieval) \\ Universidad Complutense de Madrid
}

La escultura de la catedral de Jaca ha sido objeto de estudio desde los inicios de la historiografía artística hispana y continúa concitando la atención de los investigadores $^{2}$. Su tímpano occidental es uno de los ejemplares mejor estudiados del románico español, no sólo en lo que respecta al número de publicaciones, sino también a la

1 Becario predoctoral del Programa FPU del Ministerio de Educación. El presente texto retoma algunas conclusiones de nuestro trabajo de investigación de doctorado Dogma trinitario y cultura antiherética en el románico hispano: la portada occidental de la catedral de Jaca, dirigido por los doctores Inés Ruiz Montejo y Emilio Mitre Fernández, y se enmarca dentro del proyecto de investigación nacional Arte y monarquía en el nacimiento y consolidación del reino de Aragón (1035-1134) (HAR2009-08110).

2 Para no alargar la lista de títulos, remitimos a los recogidos en D. Ocón ALONSo, "El tímpano de Jaca: nuevas perspectivas", Patrimonio artístico de Galicia y otros estudios. Homenaje al Prof. Dr. Serafin Moralejo Álvarez, III, Xunta de Galicia, 2004, pp. 217-218, notas 1-4. A éstos cabría añadir D.L. Simon, "Daniel and Habakkuk in Aragon", Journal of the British Archaeological Association, 3ª serie, XXXVIII (1975), pp. 50-54; ID., "L'art roman, source de l'art roman", Les Cahiers de Saint-Michel de Cuxa, 11 (1980), pp. 257-266; ID., La catedral de Jaca y su escultura: ensayo, Jaca, 1997; R. SALVINI, "Spagna, Tolosa o Modena? Contributo alla preistoria di Nicholaus", A.M. RomANINI (ed.), Nicholaus e l'arte del suo tempo. Atti del seminario, I, Ferrara, 1985, pp. 27-49; S. TrInks, "Hac in sculptura, lector, si gnoscere cura'. Bemerkungen zur Antikenrezeption der Skulptur in Jaca”, Pegasus, 1 (1999), pp. 35-52; D.L. Simon, “A Moses capital at Jaca”, M.L. Melero y otros (eds.), Imágenes y promotores en el arte medieval. Miscelánea en homenaje a Joaquín Yarza Luaces, Bellaterra, 2001, pp. 209-219; D. Ocón Alonso, "El sello de Dios sobre la iglesia: tímpanos con crismón en Navarra y Aragón”, R. SÁNCHEZ y J.L. SENRA (coords.), El tímpano románico: imágenes, estructuras y audiencias, Santiago de Compostela, 2003, pp. 75-101, y los recientes estudios de M.A. CAstiñeIras GonzÁlez, "Verso Santiago? La scultura romanica da Jaca a Compostella", A.C. QuintaVAlLE (ed.), Medioevo: l'Europa delle cattedrali. Atti del Convegno internazionale di studi, Milán, 2007, pp. 387-396; J.L. SenRa Gabriel y Galán, "Architecture et décor dans le contexte de la colonisation clunisienne des royaumes septentrionaux de la péninsule ibérique", Hauts lieux romans dans le sud de l'Europe (XI'-XIIe siècles). Moissac, Saint-Jacques de Compostelle, Modène, Bari..., 2008, pp. 34-40; F. Prado-VILAR, "Saevum Facinus: estilo, genealogía y sacrificio en el arte románico español", Goya, 324 (2008), pp. 184-186; S. Trinks, "Nacktheit am spanischen Pilgerweg - Antike als Antidot”, K. vAn Eickels y S. BiessenäCKER (eds.), Nacktheit im Mittelalter, Bamberg, 2008, pp. 43-56; ID., "Skulpturen in Serie: Antike als Produktivkraft im Spanien des 11. Jahrhunderts", C. LAUDE, y G. Hess (eds.), Konzepte von Produktivität im Wandel vom Mittelalter in die Frühe Neuzeit, Berlín, 2008, pp. 181-205; ID., "Schlangenikonographie zwischen León und Jaca: eine Zeichenlehre des Bösen nach Isidor von Sevilla", A. Arbeiter, C. Kothe y B. Marten (eds.), Hispaniens Norden im 11. Jahrhundert. Christliche Kunst im Umbruch $/$ El Norte hispánico en el siglo XI. Un cambio radical en el arte cristiano, Petersberg, 2009, pp. 220-234; J.E. MANN, Romanesque Architecture and its Sculptural Decoration in Christian Spain 1000-1120, Toronto, 2009, pp. 132-160. 
calidad de las mismas, el prestigio de sus autores y su repercusión internacional. Tal volumen de aportaciones ha contribuido a un conocimiento en profundidad de la obra que sugiere continuas revisiones y fomenta nuevas vías de estudio.

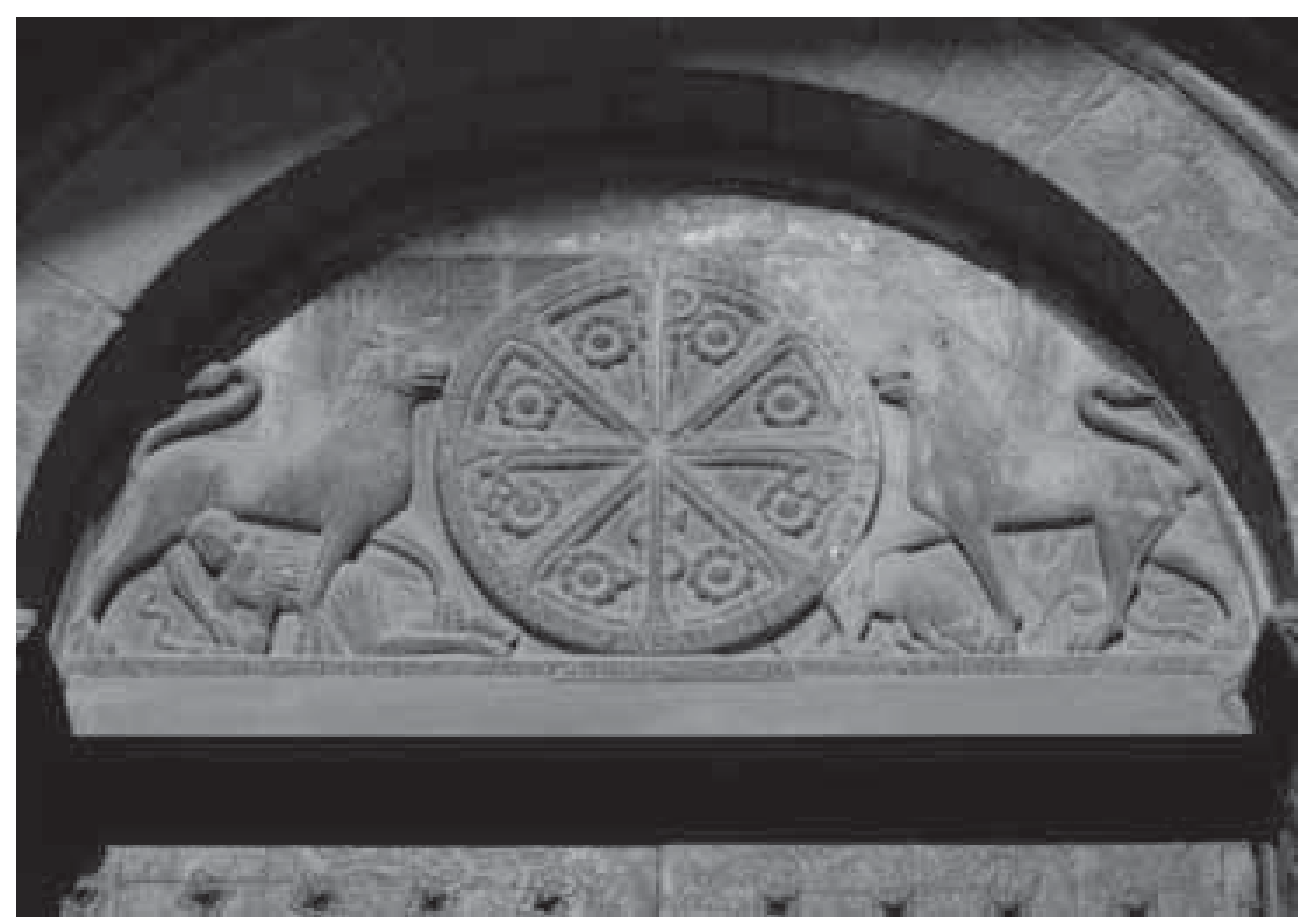

Fig. 1. Catedral de Jaca, tímpano de la portada occidental.

El tímpano jaqués (fig. 1) recoge uno de los principios básicos del cristianismo, la fe en la Trinidad, probablemente el dogma más debatido a lo largo de la Tardoantigüedad y de la Edad Media. Recurrir a las manifestaciones artísticas como medio privilegiado de afirmación doctrinal ya no resulta una novedad en el románico. Sin embargo, gracias a la dimensión pública que adquieren los programas situados a la entrada de los templos, tal objetivo se ve satisfecho con una proyección hasta entonces inusitada. La portada occidental de Jaca es un claro ejemplo de exposición dogmática, perfectamente elaborada pese a su precocidad dentro de la plástica románica ${ }^{3}$. A lo largo de estas páginas nos proponemos reflexionar sobre las circunstancias que pudieron determinar la proclamación del dogma trinitario en su tímpano. Tal objetivo conlleva preguntarse no sólo por la coyuntura histórica y religiosa de la obra, sino también por la identidad de los promotores del programa y las soluciones plásticas empleadas por los artistas, qué

3 Sobre el problema de su cronología nos detendremos en la última sección de este trabajo. 
objetivos perseguían y qué fuentes estuvieron a su disposición. Sólo a partir de estos interrogantes podremos aproximarnos a las actitudes y herramientas intelectuales puestas en marcha a la hora de elaborar un programa iconográfico como el jaqués.

\section{La significación trinitaria del tímpano}

El desciframiento de la iconografía de la portada jaquesa viene determinado por la interpretación de sus inscripciones. La que circunda el crismón (fig. 2) aporta la clave para trascender y ampliar el significado primigenio del monograma a una dimensión trinitaria: + HAC IN SCVLPTURA LECTOR SIC NOSCERE CVRA / P . PATER . A . GENITVS . DVPLEX EST SP(iritu)S ALMVS / HII TRES IVRE QVIDEM doMINVS SVNT VNVS ET IDEM ${ }^{4}$. Más allá de las diferentes lecturas y de la polémica que ha suscitado la interpretación de los versos ${ }^{5}$, nos interesa

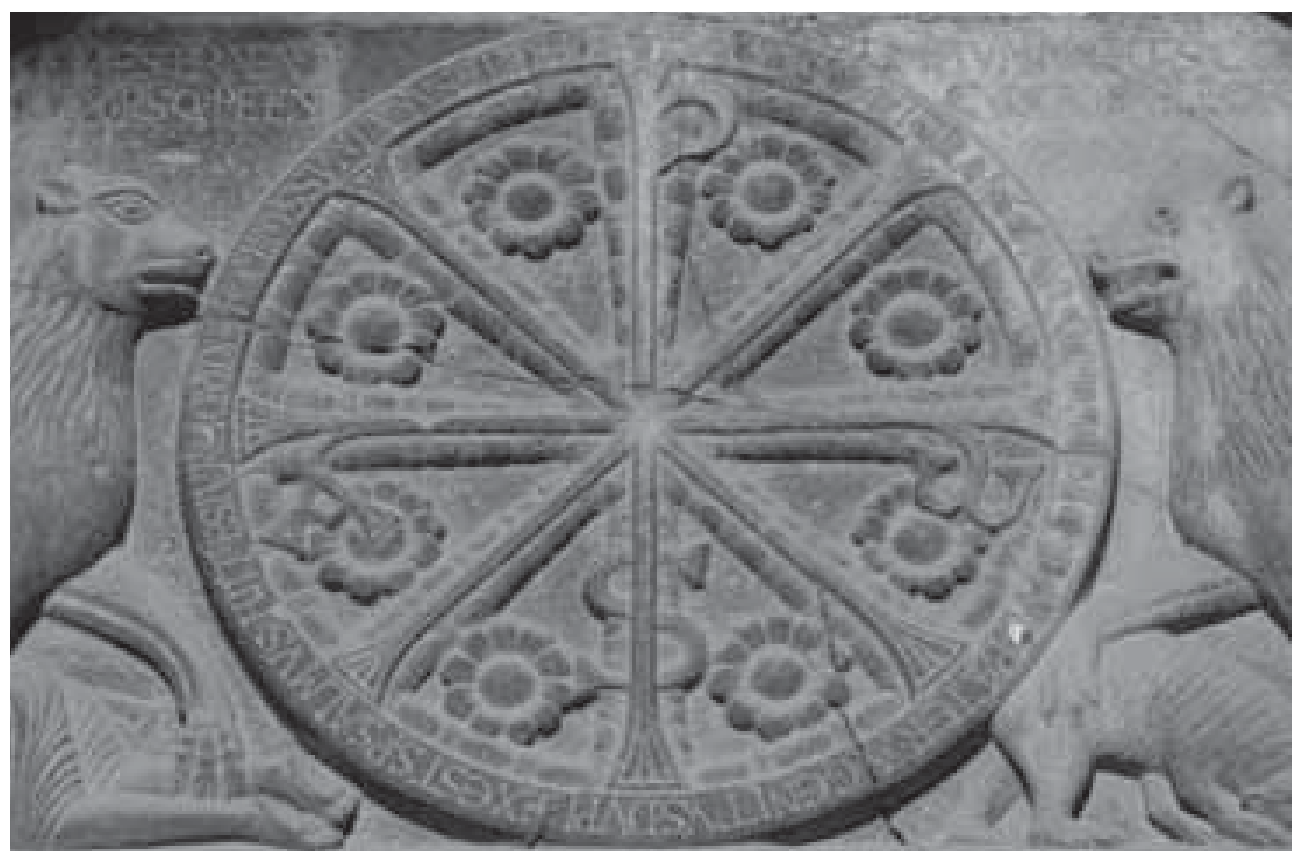

Fig. 2. Catedral de Jaca, tímpano de la portada occidental, crismón.

4 En esta escultura, lector, procura entender de este modo: / la P es el Padre, la A el Engendrado, la [letra] doble es el Espíritu Santo / Estos tres son, por derecho y sin duda, un único y mismo Señor.

5 Diferentes aportaciones de la década de 1990, a las que remitimos, dieron un giro a la interpretación del tímpano y de su crismón y lograron asentar un cierto consenso entre los especialistas: J.F. EsTEBAN LoRENTE, "Las inscripciones del tímpano de la catedral de Jaca”, Artigrama, 10 (1993), pp. 143-161; ID., "El tímpano de la Catedral de Jaca (continuación)", Aragón en la Edad Media, XIV-XV (1999), pp. 451-472; R. FAVREAU, "Les inscriptions du tympan de la cathédrale de Jaca", Académie des Inscriptions et Belles-Lettres. Comptes rendus des séances de l'année 1996, II, pp. 535-559; C.B. Kendall, "The Verse Inscriptions of the Tympanum of Jaca and the Pax Anagram", Mediaevalia, 19 (1996), pp. 405-434; ID., The Allegory of the Church. Romanesque Portals and Their Verse Inscriptions, Toronto-Buffalo-Londres, 1998, pp. 122-138. 
la dimensión doctrinal que éstos aportan al programa. Hemos de tener en cuenta que inscripciones como la del crismón jaqués, pese a la concisión impuesta por la epigrafía, se revelaban como auténticos condensadores semánticos para los espectadores de su tiempo ${ }^{6}$. De este modo, sus versos eran capaces de activar distintos niveles de significado en un lector instruido.

El primero de los tres hexámetros contiene una interesante advertencia al fiel que no compromete la precisión teológica del símbolo. El tercero también es claro en su formulación. Establece que las tres personas de la Trinidad, Padre, Hijo y Espíritu Santo comparten una misma y única naturaleza divina. Tal sentencia es una proclamación del dogma trinitario desde la estricta ortodoxia fundada en la reflexión patrística y en las profesiones de fe de los primeros concilios. La elección de determinados términos o calificativos en el segundo hexámetro, aun correspondiendo a imperativos métricos o poéticos, traduce una intencionalidad dogmática. Así, Genitus -en lugar del habitual Filius - enfatiza la naturaleza divina de la segunda persona ${ }^{7}$. El poema De Sobrietate del carolingio Milon de Saint-Amand ( $\left.† 872\right)$, identificado por R. Favreau como la fuente de los versos jaqueses ${ }^{8}$, corrobora la alusión implícita a la doble procedencia del Espíritu Santo en el tímpano apuntada por J.F. Esteban ${ }^{9}$. Si el ideólogo del programa jaqués se sirvió del poema carolingio para componer los hexámetros del crismón, sin duda conoció las palabras del poeta referidas al Paráclito: ab utroque venit quia spiritus almus (...) Compar et cequalis patri natoque cocvus ${ }^{10}$. Esta apostilla condensa la postura occidental respecto a las relaciones intratrinitarias de la tercera persona ${ }^{11}$.

6 Señala Favreau que "el conocimiento profundo de los textos que tenían los autores de inscripciones medievales los podía conducir a acercamientos, a citas aproximativas, a alusiones que se nos escapan fácilmente", del mismo modo que un lector provisto del bagaje intelectual adecuado podía completar sin dificultad el significado de las citas abreviadas. Vid. R. FAVREAU, "Les inscriptions médiévales. Reflet d'une culture et d'une foi”, Études d'épigraphie médiévale, Limoges, 1995, pp. 270-271.

7 El término Filius, empleado en los símbolos de Nicea y Constantinopla (H. Denzinger y P. HüNERMANN, El magisterio de la Iglesia. Enchiridion symbolorum definitionum et declarationum de rebus fidei et morum, Barcelona, 1999, pp. 92 y 110), resultaba menos preciso a la hora de destacar la naturaleza de la filiación del Hijo; en cambio, Genitus indicaba claramente su consustancialidad con el Padre, pues aludía a la generación eterna de la segunda persona por la primera. Fue utilizado también en el III Concilio de Toledo (589), en el que se condenó el arrianismo, y en el XI Concilio de Toledo (675), entre otros. Vid. J. ViVEs (ed.), Concilios visigóticos e hispano-romanos, Barcelona-Madrid, 1963, pp. 118 y 347. Alcuino de York, que desempeñó un papel clave en la represión del adopcionismo desde los círculos carolingios, también se valió del término Genitus para designar al Hijo (R. FAVREAU, "Les inscriptions du tympan...", op. cit., p. 553).

8 R. FAVREAU, "Note complémentaire à propos d'une inscription du tympan de la cathédrale de Jaca (Aragon)", Académie des Inscriptions et Belles-Lettres. Comptes rendus des séances de l'année 2004, I, pp. 7-10. Como reconoce Favreau, para interpretar la leyenda inscrita ya no sería necesario recurrir al comentario de Atton de Vercelli señalado como fuente del verso en 1996 (R. FAVREAU, "Les inscriptions...”, op. cit., pp. 551-553).

9 J.F. Esteban Lorente, "Las inscripciones...", op. cit., p. 154.

10 "El Espíritu Santo procede de uno y del otro (...) semejante e igual al Padre y contemporáneo del Hijo".

11 Vid. E. Mitre Fernández, "El Cisma de Oriente y la configuración del dogma trinitario", Erytheia, 7.1 (1986), p. 11. 
La inusitada precisión dogmática del crismón jaqués, su insistencia en conceptos clave de la ortodoxia trinitaria y, en suma, la singularidad de la portada que lo acoge suscitan un interrogante ineludible: ¿qué motivó una proclamación doctrinal como ésta en el contexto aragonés de finales del siglo XI? Ante los ambiciosos planteamientos teológicos que revela la obra no podemos contentarnos con una respuesta única. Concurrirían diversas motivaciones y unos destacados promotores capaces de dar forma, con el concurso de un excepcional taller escultórico, a un denso programa iconográfico en el que los múltiples significados se imbrican de forma magistral. En programas de un calado doctrinal como el de Jaca han de contemplarse dos aspectos interrelacionados como incentivo para el promotor de la obra. Por un lado, la conmemoración del dogma per se, como verdad de fe que conviene manifestar y hacer patente. Por otro lado, la posible incidencia de corrientes heterodoxas en la inquietud de los mentores por una determinada proclamación. Ambos factores pueden estar detrás de una elección plástica y en ambos casos es necesario retrotraerse a los fundamentos doctrinales del dogma. La vigencia del legado patrístico y conciliar en los siglos medievales, así como la persistencia de antiguos errores recurrentes en el panorama teológico contemporáneo -si no reactivados, al menos evocados- requieren una visión retrospectiva por parte del investigador. Las grandes portadas del románico constituyen ante todo exposiciones de la ortodoxia de validez universal. Su conmemoración del dogma es de continua actualidad, con independencia de la existencia puntual de movimientos disidentes o de polémicas doctrinales influyentes en mayor o menor grado en su horizonte cronológico ${ }^{12}$. En un afán por escudriñar los fundamentos ideológicos de las imágenes, se puede caer en el error de ajustar un discurso plástico a una querella doctrinal o a la aparición o persistencia de una determinada herejía, sin que tales problemas revistieran actualidad para un enclave determinado o preocuparan al promotor de la obra. Veamos en qué medida la portada jaquesa responde a esta problemática.

\section{El debate trinitario a finales del siglo XI}

La tarea de rastrear posibles herejías trinitarias en los años finales del siglo XI entraña una gran complejidad. Además de la parquedad de las fuentes, hemos de hacer frente a la destrucción de la literatura emanada de la heterodoxia, de modo que los puntos fundamentales de su doctrina han de colegirse de lo señalado por las fuentes canónicas. La fidelidad de éstas al pensamiento del "otro" religioso es cuestionable, ya que incurren en distorsiones inherentes a todo discurso apologético. Pese a ello, nos interesa recuperar precisamente la voz del apologeta, pues es la ideología del mentor la que acaba reflejándose en su promoción artística.

12 Estos valores de universalidad y permanencia son característicos de los programas epigráficos desplegados con vocación publicitaria, como es el caso de Jaca. Vid. R. FAVreau, "L'épigraphie médiévale", Cahiers de Civilisation Médiévale, XII, 4 (1969), p. 395. 
J. Wirth se muestra tajante en su estudio de la imagen románica, negando la existencia de debates de carácter dualista o trinitario en estos momentos ${ }^{13}$. Sin embargo, el triteísmo de Roscelin de Compiègne (c.1050-c.1120/1125), cuya refutación implicó a una de las figuras más destacadas del panorama teológico contemporáneo -San Anselmo- merece nuestra atención por su posible relación con los mensajes desplegados en el tímpano jaqués.

En los siglos altomedievales la doctrina sobre la Trinidad no había experimentado grandes cambios respecto al corpus patrístico y a las proclamaciones conciliares de los primeros siglos. Su evolución se concretó en una sistematización del magisterio eclesial y del legado de los Padres de la Iglesia, fundamentalmente de San Agustín ${ }^{14}$. Quizá el aspecto más reseñable es el auge que el misterio trinitario experimentó en el ámbito litúrgico, fenómeno revelador de su consideración como objeto central de la $\mathrm{fe}^{15}$. A finales del siglo XI la introducción la teología dialéctica impuso la necesidad de armonizar razón y revelación. San Anselmo (1033-1109) inauguró esta nueva vía en el estudio de Dios y su obra nos compete de modo especial por abordar recurrentemente el dogma de la Trinidad ${ }^{16}$. Su De Fide Trinitatis et de incarnatione Verbi (c. 1092-1094) contra Roscelin de Compiègne reviste especial interés por su compromiso apologético ${ }^{17}$. La concepción triteísta del dogma representada por Roscelin hundía sus fundamentos en el problema de la validez de los conceptos universales, reduciendo la Trinidad a una cuestión nominal. Desde premisas nominalistas no era posible conciliar la unidad de la divinidad con la existencia de las tres personas, prin-

13 “'On serait bien en peine de trouver, autour de 1100, des hérétiques s'inspirant d'Arius (dont l'œuvre est détruite) ou, plus largement, des hérésies antitrinitaires” (J. WIRTH, L'image à l'époque romane, París, 1999, p. 214).

${ }^{14}$ E. Gössmann, Fe y conocimiento de Dios en la Edad Media, Madrid, 1975 (Friburgo de Brisgovia, 1971), p. 3. Un panorama del periodo, circunscrito al ámbito occidental, en A. Michel, "La théologie latine du VI ${ }^{\mathrm{e}}$ au XX $\mathrm{X}^{\mathrm{e}}$ siècle. 1. De Boèce au IVe concile du Latran”, A. Vacant, E. Mangenot y E. Amann (dirs.), Dictionnaire de théologie catholique, voz "Trinité. III", XV/2, París, 1950, cols. 1702-1730.

15 Por ejemplo, Alcuino, autor de De fide sanctae Trinitatis, compuso una misa dominical de Trinitate, preludio de la posterior fiesta litúrgica de la Trinidad, y Esteban de Lieja redactó a comienzos del siglo X un oficio completo sobre la Trinidad para el domingo posterior a Pentecostés. Vid. F. CABrol, "Le culte de la Trinité dans la liturgie et l'institution de la fête de la Trinité”, Ephemerides Liturgicae, XLV (1931), pp. $275-277$. Resulta de interés comprobar que este último día del calendario llegó a ser fijado para recibir a los herejes en la Iglesia (ibid., p. 278).

16 En el Monologion (c. 1076), dedicado a la demostración de la existencia de Dios, estudia la unidad de la divinidad y la cuestión trinitaria. Es autor, además, de los tratados De processione Spiritus Sancti (c. 1102) y Cur Deus homo (c. 1094-1098). Si en el primero defiende el Filioque frente a los orientales, en el segundo trata entre otros temas las relaciones del Verbo encarnado con la Trinidad. Vid. R. Roques, "Introduction", Anselmo de Canterbury, Pourquoi Dieu s'est fait homme [Cur Deus Homo], París, 1963, pp. 45 y 151-154.

17 Vid. A. Wilmart, "Le premier ouvrage de saint Anselme contre le trithéisme de Roscelin", Recherches de Théologie Ancienne et Médiévale, 3 (1931), pp. 20-36, y los trabajos de Constant Mews recogidos en C.J. Mews, Reason and Belief in the Age of Roscelin and Abelard, Ashgate, 2002: "St. Anselm and Roscelin: some new texts and their implications. I. The De incarnatione verbi and the Disputatio inter christianum et gentiles" (1991), "The Trinitarian Doctrine of Roscelin de Compiègne and its influence. Twelfth-Century Nominalism and Theology Re-considered" (1997), y "St. Anselm and Roscelin of Compiègne: Some new texts and their implications. II. A vocalist essay on the Trinity and intellectual debate c. 1080-1120" (1998). 
cipio clave de la reflexión patrística sobre el dogma. Roscelin, por tanto, consideraba al Padre, al Hijo y al Espíritu Santo como tres seres separados -tres res per se separatim; substantia trina et triplex ${ }^{18}-$, y sus detractores lo acusaban de contemplar la existencia de tres dioses dentro de la Trinidad. Las tesis triteístas fueron condenadas oficialmente en Soissons en 1092 y Roscelin hubo de retractarse ${ }^{19}$.

Resultaría de gran interés poder conectar la polémica triteísta con la afirmación trinitaria del tímpano jaqués. La estricta contemporaneidad de una y otra invita a ello. En este sentido se pronunció J.F. Esteban señalando que "esta cuestión, aunque citada, no ha sido suficientemente destacada, pero el triteísmo debió ser algo frecuente en ambos lados del Pirineo central, a juzgar por la abundancia de representaciones trinitarias" ${ }^{20}$. En efecto, los paralelos entre el debate triteísta y la exégesis de las inscripciones jaquesas son innegables ${ }^{21}$. Sin embargo, esta hipótesis plantea algunas objeciones.

En primer lugar, no tenemos constancia documental de un conocimiento en Aragón de la polémica tristeísta ${ }^{22}$. Las fuentes nada dicen al respecto de una hipotética toma de partido en el debate por parte del clero aragonés. La posibilidad de un conocimiento de dicha controversia trinitaria quizá residiera en la procedencia de sus elites religiosas. Sin embargo, pese a los patentes efectos de la "colonización" eclesiástica foránea, el origen de los francos llegados a Aragón ha de buscarse primordialmente en los Pirineos franceses y el Languedoc ${ }^{23}$, mientras que los centros

18 A. Forest y otros, El pensamiento medieval, vol. XIV de A. Fliche y V. Martin (dirs.), Historia de la Iglesia, Valencia, 1974 (París, 1951), pp. 49 y 75.

19 Su discípulo Abelardo y Gilberto de la Porrée fueron receptivos a la interpretación del dogma en clave nominalista, acusados por ello de menoscabar la unidad de Dios en sus escritos trinitarios, y forzados a retractarse en 1141 y 1148 respectivamente. Vid. C.J. Mews, "The Council of Sens (1141): Abelard, Bernard, and the Fear of Social Upheaval”, Speculum, 77/2 (2002), pp. 342-382, y la bibliografía citada en p. 343, n. 2; A. Hayen, "Le Concile de Reims et l'erreur théologique de Gilbert de la Porrée", Archives d'histoire doctrinale et littéraire du Moyen-Âge, 10-11 (1935-1936), pp. 29-102.

20 J.F. Esteban Lorente, "Unas cuestiones simbólicas del románico aragonés", Aragón en la Edad Media, VIII (1989), p. 210 (ya apuntado en ID., "Las inscripciones...", op. cit., p. 156). Vid. también D. OcóN Alonso, "Problemática del crismón trinitario", Archivo Español de Arte, LVI, 223 (1983), p. 253, n. 33; R. FAVREAU, "Les inscriptions du tympan...", op. cit., p. 553.

21 San Anselmo refiere el siguiente argumento de Roscelin en su Epistola 128 y De Incarnatione Verbi: Si tres personae sunt una tantum res et non sunt tres res unaquaeque per se separatim (...) ergo pater et spiritus sanctus cum filio incarnatus est. En otro lugar critica la limitación de esa aproximación nominalista a la Trinidad: qualiter in illa secretissima et altissima natura comprehendet quomodo pluses personae, quorum singula quaeque perfectus est deus, sint unus deus? (...) qualiter discenter inter unum deum et trinam relationem eius? Vid. C.J. Mews, "St. Anselm and Roscelin... (II)", op. cit., pp. 42 y 46.

22 Como veremos, las pocas alusiones a corrientes heterodoxas que se encuentran en las fuentes son las mencionadas en las cartas papales y se refieren a errores del pasado.

${ }^{23}$ Vid. los estudios de P. Ga Mouton sobre los francos instalados en Jaca y en el reino de Aragón en estas décadas: P. García Mouton, Influencia francesa en España en los siglos XI al XIII, tesis doctoral inédita (U.C.M., 1979), pp. 38-71; ID., "Los franceses en Aragón (siglos XI-XIII)", Archivo de Filología Aragonesa, XXVI-XXVII (1980), pp. 7-98. Ha de reconocerse, aun así, la relación contraída por Sancho Ramírez con el norte francés tras sus nupcias con Felicia de Roucy. 
del debate fueron a priori ajenos a este ámbito meridional. Pero, ante todo, la cuestión de fondo reside en la actualidad y oportunidad de la contienda entre Anselmo y Roscelin para la Iglesia aragonesa, inmersa en cambios sustanciales desde el punto de vista institucional y litúrgico que orientarían primordialmente sus intereses hacia otras direcciones. Argumentos de orden histórico-artístico pueden aducirse también. Resultaría excepcional que tal controversia trinitaria hubiera dado lugar a un programa iconográfico tan ambicioso y elaborado como el de Jaca cuando, en áreas más próximas a los centros de la polémica, no conocemos expresiones artísticas del dogma con un carácter antitriteísta parangonable al que se ha querido ver en Aragón. Por ello, no parece claro que el triteísmo fuera un condicionante de peso a la hora de plasmar en Jaca el dogma trinitario.

\section{Tradición y reforma: Aragón en la encrucijada}

En nuestra opinión, la pertinencia y actualidad del mensaje del tímpano jaqués responde a las circunstancias de la Iglesia aragonesa de finales del siglo XI y a los procesos de inserción del reino en el contexto internacional, aspectos ya invocados por otros autores al enmarcar la actividad artística catedralicia. Roma se ofrecía como referencia legitimadora para el flamante reino, y Sancho Ramírez (10641094) pudo comprobarlo de primera mano en su viaje a la Santa Sede en $1068^{24}$. Algunas iniciativas que han de conectarse con la nueva alianza papal tuvieron gran calado en la vida eclesiástica aragonesa. La principal de ellas fue la sustitución de la liturgia hispana por la romana (1071) en el marco de la reforma propugnada por los pontífices ${ }^{25}$. En este sentido, creemos necesario retomar un factor que la historiografía artística ha traído a colación en otras ocasiones para perfilar el marco ideológico del arte creado en los albores del románico hispano ${ }^{26}$ : los recelos que los particularismos litúrgicos nacionales despertaban en la curia romana. El rito hispano era considerado rayano en la heterodoxia, proclive a las desviaciones doctrinales y a la superstición, y, en tanto que soporte de antiguos errores -entre los

24 L. García-Gujurro Ramos, "El Papado y el Reino de Aragón en la segunda mitad del siglo XI", Aragón en la Edad Media, XVIII (2004), pp. 245-264, destaca las ventajas mutuas que supuso la vinculación de Aragón con Roma. Con esta unión, el papado se fortalecía extendiendo su influencia conforme a las directrices de la reforma eclesiástica, materializadas en la institución de la cruzada y en la exención de la jurisdicción diocesana para los institutos eclesiásticos, que pasaban a depender directamente de Roma. Por su parte, el reino de Aragón se veía legitimado, reafirmaba su cohesión política y consolidaba su progresiva expansión. Estudios pioneros y aún esenciales para acercarse al fenómeno son los de P. KeHR, "Cómo y cuándo se hizo Aragón feudatario de la Santa Sede", Estudios de Edad Media de la Corona de Aragón, I (1945), pp. 285-326; ID., "El papado y los reinos de Aragón y Navarra hasta mediados del siglo XII”, Estudios de Edad Media de la Corona de Aragón, II (1946), pp. 74-186.

25 Vid. A. Ubieto ArtetA, "La introducción del rito romano en Aragón y Navarra", Hispania Sacra, I (1948), pp. 299-324. Una visión más reciente sobre el problema en D.J. Sмітн, "Sancho Ramírez and the Roman Rite", R.N. Swanson (ed.), Unity and Diversity in the Church, Oxford, 1996, pp. 95-105.

26 Vid. por ejemplo el análisis de R. WALKer, Views of Transition. Liturgy and Illumination in Medieval Spain, Londres-Toronto, 1998, pp. 21-45. 
que se invocaba al priscilianismo y al arrianismo- era susceptible de generar otros nuevos ${ }^{27}$. Tales sospechas inquietaban sin duda en el mundo hispánico, interesado en demostrar su ortodoxia y legitimidad ante los sucesivos escrutinios romanos ${ }^{28}$.

Países con diferencias litúrgicas como España fueron vistos como sospechosos y monopolizaron buena parte de los esfuerzos centralizadores de la política de la Santa Sede $^{29}$. Siguiendo una retórica hasta cierto punto habitual en tiempos de la reforma, Gregorio VII (1073-1085) había descrito con crudeza el deterioro de la cristiandad hispana en una misiva dirigida a los reyes de Castilla y Navarra el 19 de marzo de $1074^{30}$. En ella instaba a aceptar "no la disciplina de Toledo o de cualquier otra iglesia", sino el ordo y officium de la Iglesia romana, contra la que "las lenguas de los herejes nunca pudieron prevalecer" 31 . Estas acusaciones tan categóricas no fueron las únicas de aquellos años. En un privilegio papal dirigido al abad Aquilino de San Juan de la Peña en 1071, Alejandro II (1061-1073) había tachado a la liturgia hispana de rito confuso ${ }^{32}$, y en la bula Apostolica sedes, fechada hacia 1084-1085, se contraponía la "despreciable superstición de la ilusión toledana” a la "ley y costumbres

27 J. OrLandis, “Toletanæ illusionis superstitio”, Scripta Theologica, 18 (1986), pp. 197-213; E. MitrE FERnÁNDEZ, "Herejías y comunidades nacionales en el medievo", Ilu, 1 (1996), p. 92.

28 Según unas noticias incorporadas en el Codex Aemilianensis, el legado pontificio Zanelo había sido enviado en el siglo X desde la Santa Sede con el objetivo de revisar la ortodoxia de la liturgia nacional, y hacia 1065 el legado Hugo Cándido habría llegado a la Península para gestionar el cambio de rito. Como respuesta, una legación de obispos españoles se dirigió a Roma en 1067 llevando consigo manuscritos litúrgicos propios con el fin de que fueran examinados por la Santa Sede, cuyo fallo, como ocurriera en el siglo X, resultó favorable al rito hispano. Vid. A. Ubieto Arteta, "La introducción...”, op. cit., pp. 301 y 307; P. Kehr, “Cómo y cuándo...", op. cit., pp. 294-296; ID., "El papado...”, op. cit., p. 93. Mientras que Ubieto y Kehr dieron crédito al relato, defendiendo su veracidad, P. David impugnó los textos que lo apoyaban, opinión compartida recientemente por T. Deswarte. Vid. P. DAVID, Études historiques sur la Galice et le Portugal du VI ${ }^{e}$ au XII ${ }^{e}$ siècle, Lisboa-París, 1947, pp. 112-116 y 391-395; T. DESWARTE, "Une chrétienté hérétique? La réecriture de l'histoire d'Espagne par Grégoire VII", P. Chastang (dir.), Le passé à l'épreuve du présent. Appropriations et usages du passé au Moyen Âge et à la Renaissance, París, 2008, pp. 178-180.

${ }_{29}$ Como recuerda E. Mitre, "sistematizar la persecución de la herejía o extender las acusaciones de heterodoxia serán actividades inseparables del fortalecimiento del poder papal” (E. Mitre FernÁndez, Iglesia, herejía y vida política en la Europa medieval, Madrid, 2007, p. 63).

30 D. Mansilla, La documentación pontificia hasta Inocencio III (956-1216), Roma, 1955, doc. nº 8, pp. 15-16.

31 Sed postquam vesania Priscillianistarum diu pollutum et perfidia Arrianorum depravatum, et a Romano ritu separatum, irruentibus prius Gothis, ac demum invadentibus Saracenis, regnum Hyspaniae fuit, non solum religio est diminuta, verum etiam mundane sunt opes labefactae. (...) Romane ecclesie ordinem et officium recipiatis, non Toletane vel cuiuslibet alie, sed istius, que a Petro et Paulo supra firmam petram per Christum fundata est et sanguine consecrata, cui porte inferni, id est lingue hereticorum, unquam prevalere potuerunt, sicut cetera regna Occidentis et Septemtrionis teneatis (ibid., pp. 15-16). Para la actitud de Gregorio VII ante la liturgia y disciplina eclesiástica hispanas -aspecto ya abordado en su momento por J.F. RIVERA RECIO, "Gregorio VII y la liturgia mozárabe", Revista Española de Teología, II (1942), pp. 18-19, y F. PÉrEZ, "San Gregorio VII y la Liturgia española”, Liturgia. Revista benedictina, III, 28-29 (1948), pp. 105-113- vid. J.M. Soto RÁBAnOs, "Introducción del rito romano en los reinos de España. Argumentos del papa Gregorio VII", Studi Gregoriani, 14 (1991), pp. 161-174; T. Deswarte, “Une chrétienté hérétique...", op. cit.

32 [Hugo Cándido] confusos ritus divinorum obsequiorum ad regulam et canonicum ordinem reformavit (D. Mansilla, La documentación..., op. cit., doc. $\mathrm{n}^{\circ}$ 4, p. 8). Se trata de la bula conocida como Apostolice sedis, en la que Alejandro II lamenta el estado de la Iglesia aragonesa y alaba el activo papel del legado Hugo Cándido en la introducción de reformas en el reino. 
romanas" ${ }^{\prime 33}$. Este documento, salido de la cancillería de Gregorio VII, reviste especial interés por la posible implicación del obispo García de Jaca en su elaboración ${ }^{34}$.

Las críticas a los particularismos litúrgicos nacionales obedecían a una concepción herética y cismática de la cristiandad hispana en su conjunto ${ }^{35}$. De este modo, las acusaciones de heterodoxia acabaron desbordando el plano meramente doctrinal para cobrar una acusada dimensión política. Algo semejante había acontecido pocos siglos atrás cuando los intelectuales carolingios llegaron a hacer de la cuestión adopcionista un problema de imperio ${ }^{36}$. La opinión formada que podían manejar Roma o el mundo franco en el siglo XI debía inquietar sin duda tanto a las elites eclesiásticas aragonesas como a Sancho Ramírez, preocupado por asegurar su potestad regia y la estabilidad de su reino tendiendo alianzas con estos poderes foráneos. En el caso hispano, lo doctrinal y lo disciplinar iban de la mano. Instaurar el ordo romanus conllevaba el restablecimiento de una pretérita unidad romana, rota y olvidada con el paso de los siglos, y reivindicada insistentemente por los pontífices, en especial por Gregorio VII ${ }^{37}$. La llamada "Donación de Constantino", un decreto apócrifo falsificado - pero considerado auténtico en aquellas fechas- era el motivo esgrimido por la Santa Sede en sus pretensiones por ver reconocida su autoridad en los reinos cristianos de occidente. No de forma casual, un monumental crismón de

33 Kehr destaca las irregularidades históricas del documento, que atribuye a Ramiro I la introducción de la liturgia romana y lo hace pionero en el vasallaje a San Pedro. Sin embargo, el autor defiende la autenticidad diplomática de la bula, contemplándola como una maniobra del obispo jaqués García, quien, atribuyendo a su padre el mérito de la sustitución del rito, menoscababa así la figura de su hermano Sancho. Vid. P. KeHr, "Cómo y cuándo...", op. cit., pp. 289-293. Damian Smith también da crédito a su autenticidad (D.J. SMITH, "Sancho Ramírez...", op. cit., p. 104, n. 45), a diferencia de Durán Gudiol, quien la considera una falsificación (A. DURÁN Gudiol, La Iglesia de Aragón durante los reinados de Sancho Ramírez y Pedro I (1062?-1104), Roma, 1962, pp. 147-149 y 177-178). El texto de la bula se reproduce en P. KeHr, “Cómo y cuándo...”, op. cit., pp. $314-317$.

34 Ibid., p. 292; D.J. Buesa Conde, Sancho Ramírez, rey de aragoneses y pamploneses, Zaragoza, 1996, pp. 163-164. Tal hecho, aun respondiendo a los intereses personales del prelado, resulta significativo de cómo las ideas difundidas desde Roma respecto a la cristiandad hispana pudieron ser asumidas por parte del clero aragonés.

35 T. Deswarte, “Une chrétienté hérétique...", op. cit., pp. 177-178.

36 Vid. A. Barbero de Aguilera, "Los 'síntomas españoles' y la política religiosa de Carlomagno", En la España medieval, 4 (1984), pp. 87-138.

37 En su carta pastoral a los reyes y nobles de España del 28 de junio de 1077 afirmaba que "el reino de España pertenece a san Pedro y a la Santa Iglesia Romana, en la manera que consta en las concesiones. Este hecho, no hay duda, ha permanecido oscuro hasta el presente, parte debido a los desórdenes de tiempos pretéritos, y parte a cierta indiferencia en nuestros predecesores (...) Pero ahora (...) no estamos dispuestos a pasar por alto este asunto por más tiempo" (E. Gallego Blanco, Relaciones entre la Iglesia y el estado en la Edad Media, Madrid, 1973, p. 159. Texto original de la carta en D. Mansilla, La documentación..., op. cit., doc. $\mathrm{n}^{\circ}$ 13, pp. 21-25). La pertenencia de España al Patrimonium Petri ya había sido reivindicada por el pontífice cuatro años antes en una carta dirigida a los príncipes que quisieran adentrarse en territorio hispano (D. MANSILLA, La documentación..., op. cit., doc. $\mathrm{n}^{\circ}$ 6, p. 12). Para las pretensiones pontificias de soberanía sobre los reinos peninsulares vid. B. LlorCA, "Derechos de la Santa Sede sobre España. El pensamiento de Gregorio VII", A. FLICHE, Reforma Gregoriana y Reconquista, vol. VIII de A. Fliche y V. MARTIN (dirs.), Historia de la Iglesia, op. cit., pp. 551-575; A. Oliver, “Regnum Hispaniae’ en el programa de reforma de Gregorio VII", Studi Gregoriani, 14 (1991), pp. 75-82. 
resonancias constantinianas fue emplazado en el tímpano catedralicio jaqués ${ }^{38}$. El antiguo símbolo, renovado ahora por su dimensión trinitaria, conmemoraba mejor que cualquier otro emblema el restablecimiento del vínculo papal granjeado por la vuelta a la ortodoxia. La consustancialidad de las personas divinas enfatizada por el mensaje del tímpano constituía el principio dogmático fundamental cuestionado por las herejías que jalonaban el supuesto pasado herético hispano. De este modo, el renacer de la unidad romana y cristiana, tras una fractura histórica dominada por el cisma, la herejía y las invasiones ${ }^{39}$, se concretaba en términos plásticos ${ }^{40}$ en un espacio propagandístico por excelencia como el de la portada de la catedral (fig. 3).

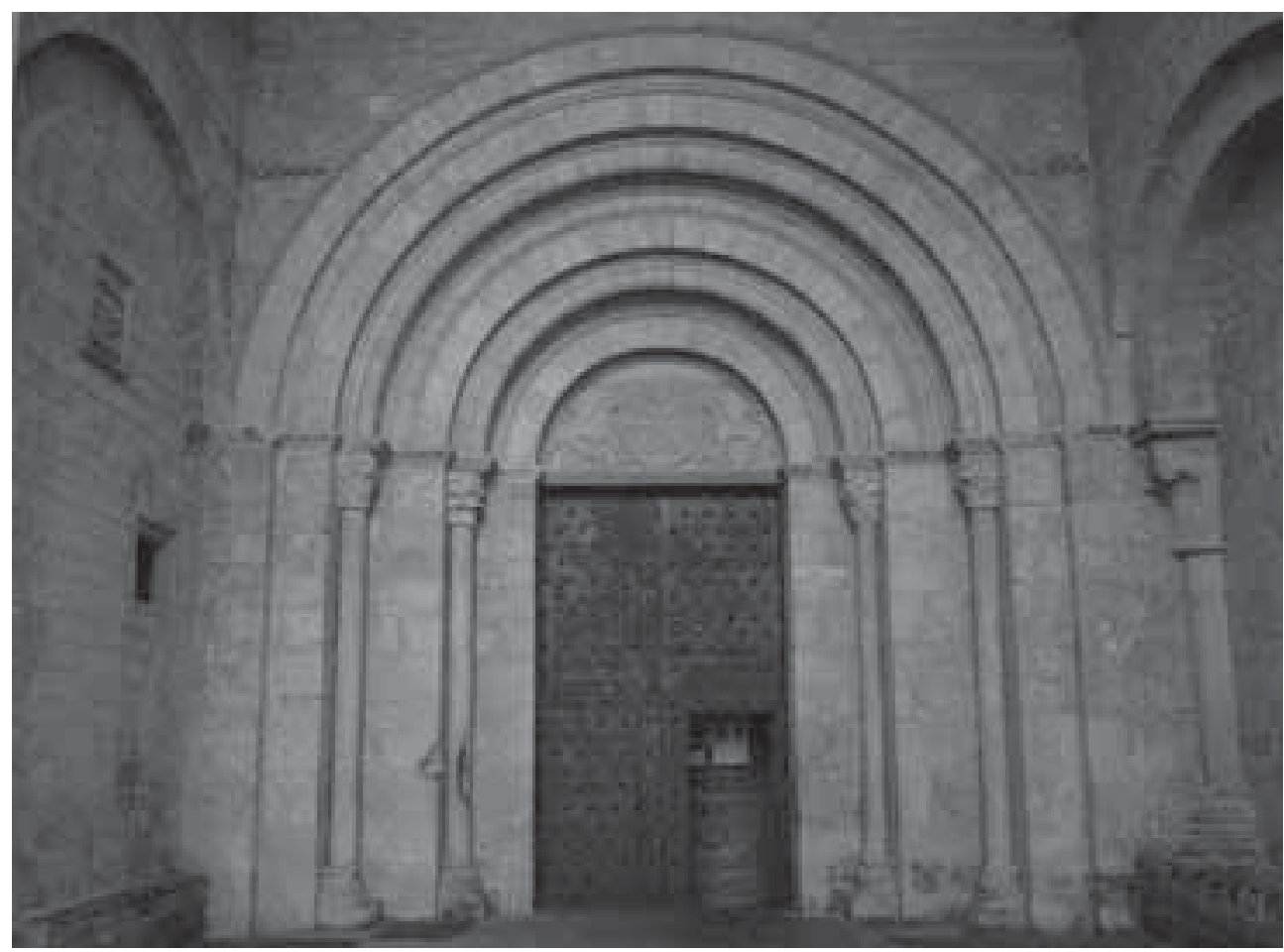

Fig. 3. Catedral de Jaca, portada occidental.

38 Abundando en la conexión con el imaginario constantiniano, no se ha reparado -que sepamos- en el hecho de que los conceptos contenidos en la célebre leyenda asociada al lábaro imperial Hoc signo tuetur pius / hoc signo vincitur inimicus tienen un paralelo visual en los grupos que flanquean el crismón jaqués: bajo forma leonina, Cristo protege al que se apiada y vence a las fuerzas del mal.

39 T. Deswarte, "Une chrétienté hérétique...", op. cit., pp. 181-185.

40 Para una valoración del programa escultórico catedralicio en el marco de la renovatio paleocristiana auspiciada por la reforma vid. D. Ocón Alonso, "El tímpano...", op. cit., pp. 224-225; ID., "El sello...", op. cit., pp. 93-96. Corresponde a la autora el haber interpretado convincentemente el crismón jaqués como signo de fidelidad de los reyes de Aragón a Roma (ibid., p. 97), argumento que hemos querido retomar en este trabajo apoyándolo desde consideraciones doctrinales relacionadas con la política eclesiástica aragonesa y romana de finales de la undécima centuria. 
La intención del monarca y de sus clérigos iría encaminada a mostrarse dentro de la ortodoxia romana, y quienes concibieron el tímpano catedralicio buscarían los referentes canónicos que podrían adquirir una especial resonancia en un ambiente de reforma eclesiástica.

El afán del emergente reino por escenificar su ortodoxia y comunión eclesial encontró una óptima ubicación para ser expuesto en una institución confiada a los canónigos de San Agustín, agentes predilectos de la Santa Sede en la difusión de la reforma ${ }^{41}$. Pero, ¿por qué la Trinidad como objeto de propaganda? El recurso a dicho dogma como manifestación por excelencia de rectitud y de fidelidad a Roma es comprensible. No sólo entroncaba con un sentir propio de la Iglesia hispana ${ }^{42}$, sino que se erigía en canon de ortodoxia: la fe en la Trinidad "acabaría constituyendo la principal seña de identidad del Cristianismo", de modo que "su conculcación pasó a convertirse en la herejía por excelencia, tanto en la legislación canónica como en la civil" "43. La proclamación del dogma trinitario expresaba, como ningún otro, el compromiso de Aragón y de sus dirigentes con la reforma recientemente adoptada. El tímpano traducía en términos teológicos las nuevas alianzas establecidas mediante una nueva imagen gestada en los círculos eclesiásticos y acorde a la política regia.

En el marco descrito anteriormente debe entenderse la actualidad de los mensajes trinitarios de la portada. Por todo ello creemos que si antiguas herejías condicionaron a los mentores del programa, fue precisamente por haber sido evocadas en el contexto de la reforma del siglo XI, no porque revistieran una amenaza espiritual a las puertas de la duodécima centuria ${ }^{44}$.

La importancia dada al Espíritu Santo en la inscripción trinitaria y el trasfondo dogmático de su fuente sugieren, en primera instancia, una relación con el Cisma

41 A. FLICHE, Reforma Gregoriana..., op. cit., p. 249; N. JASPERT, "La reforma agustiniana: un movimiento europeo entre 'piedad popular' y 'política eclesiástica"”, La reforma gregoriana y su proyección en la cristiandad Occidental. Siglos XI-XII. XXXII Semana de Estudios Medievales, Gobierno de Navarra, 2006, pp. 390-391.

42 J. Vives (ed.), Concilios..., op. cit., pp. 26, 113-114, 118, 120, 187, 233-236, 347-348, 385-386, 489491; J. Janini Cuesta, "Liturgia trinitaria española en los Misales Gelasianos del siglo VIII", Anthologica Annua, 7 (1959), pp. 9-93; J. MAdoz, "La Teología de la Trinidad en los símbolos toledanos", Revista Española de Teología, IV (1944), pp. 457-477.

43 E. Mitre Fernández, "El Cisma...", op. cit., p. 11.

44 En este sentido recordaremos cómo el impacto del adopcionismo ha sido reivindicado a la hora de explicar la proliferación de crismones en el románico pirenaico. Así lo expone, no sin reservas, E. GARLAND, L'iconographie romane dans la région centrale des Pyrénées, tesis doctoral en microficha (Université de Toulouse-Le Mirail, 1995), Lille, ANRT, 1996, t. I, pp. 286-287 y t. II, p. 70. Sin embargo, la amplia bibliografía existente sobre el adopcionismo de finales del siglo VIII (Abadal, Isla o Cavadini, entre otros) nada dice acerca de su pervivencia siglos después de la polémica. T. Deswarte precisa incluso que la doctrina adopcionista, a diferencia del priscilianismo y el arrianismo, "apenas había dejado el recuerdo de una verdadera herejía” y no influyó en la particular visión de la cristiandad hispana elaborada por Gregorio VII (T. Deswarte, “Une chrétienté hérétique...", op. cit., p. 188). 
de Oriente acontecido pocas décadas atrás ${ }^{45}$. Sin obviar este referente, cabe señalar que dicha preocupación revestiría una actualidad aún más inmediata para los mentores de la portada al comprobar su incidencia en los círculos papales en la última década de siglo. En efecto, Urbano II (1088-1099), llegó a reunir un concilio en Bari en 1098 para discutir con los griegos la doctrina sobre la tercera persona ${ }^{46}$. Precisamente la materialización del vasallaje aragonés hacia la Santa Sede se produjo en el momento en que Urbano II asumió la dignidad pontificia. El nuevo papa, como hicieran sus antecesores, felicitaría efusivamente a Sancho Ramírez por las medidas reformadoras emprendidas en su reino ${ }^{47}$. La alusión implícita al Filioque tal vez pudiera entenderse como un posicionamiento de los responsables del programa jaqués a favor de Roma en la polémica ${ }^{48}$; una toma de partido que no sería ajena a los vínculos que ligaban al reino con la Santa Sede y que impregnaron la actividad artística aragonesa del momento ${ }^{49}$.

Estos indicios ayudan a explicar la emergencia de la cuestión trinitaria en el ámbito de la reforma llevada a cabo en Aragón. En el fondo se trataba también, quizás, de un reconocimiento implícito a la propia tradición ortodoxa hispana ${ }^{50}$, en la que la problemática trinitaria -y particularmente el asunto del Filioque- había ocupado un lugar capital. El mismo Gregorio VII llegó a aludir positivamente a los concilios visigodos de Toledo [IV] y Braga [II] en su misiva de 1074 a propósito del reconocimiento debido a Roma ${ }^{51}$. La necesidad de la Iglesia hispana de manifestar

45 J.F. Esteban Lorente, "Las inscripciones...", op. cit., pp. 154-155; R. FAVreau, "Les inscriptions du tympan...", op. cit., pp. 553 y 560. Es de interés comprobar la especial atención concedida al Espíritu Santo en la espiritualidad del siglo XI, constatable por las fórmulas que continuamente lo mencionan en los textos, y la extensión particular de esta devoción en el Midi francés: E. DelaruelLe, "La vie commune des clercs et la spiritualité populaire au XI siècle", La vita comune del clero nei secoli XI e XII. Atti della Settimana di Studio, 1, Milán, 1962, pp. 152-154 y n. 42.

46 Vid. la colección de ensayos recogidos en S. PAlese y G. Locatelli (eds.), Il Concilio di Bari del 1098. Atti del Convegno Storico Internazionale e celebrazioni del IX Centenario del Concilio, Bari, 1999. Poco después, hacia 1102, San Anselmo redactó su tratado De Processione Spiritus Sancti donde intentó demostrar racionalmente el Filioque.

47 Además de las palabras de Urbano II calificando al monarca de beati Petri devotissimum famulum en 1089, ya Alejandro II aludió en 1071 a la inclinación de Sancho Ramírez por la verdadera fe encarnada por la sede romana, y su predecesor Gregorio VII señaló en una carta de marzo de 1074 el papel del monarca en el cambio de rito, relacionando su nobleza con la fidelidad a Roma. Vid. L. García-GuiJArRo RAmos, "El Papado...", op. cit., pp. 254-255.

48 En 1014 Benedicto VIII introdujo oficialmente el Filioque en el credo occidental y, por consiguiente, en la liturgia eucarística. Pocos años antes, en 1009, Sergio IV había empleado el término en un documento remitido a Constantinopla como compendio de la fe. Vid. D. Ritschl, "Hijo y Espíritu. El problema de la ortodoxia. I. La controversia sobre el 'Filioque", Concilium, 148 (1979), pp. 173-174.

49 D.L. Simon, La catedral..., op. cit., pp. 16-17; J.F. EstebAn LoREnTE, "La metrología de la catedral románica de Jaca: 2", Artigrama, 15 (2000), pp. 249-250; D. Ocón Alonso, “El sello...”, op. cit., p. 97; ID., “El tímpano...", op. cit., p. 225; F. EsPañol BERTRÁn, "El castillo de Loarre y su portada románica”, Locus Amoenus, $8(2005-2006)$, p. 17.

50 Frente a las acusaciones de heterodoxia que recibió la liturgia nacional, debe señalarse la acogida de algunos de sus rasgos específicos en la tradición litúrgica europea (los llamados "síntomas hispanos").

51 D. Mansilla, La documentación..., op. cit., doc. $\mathrm{n}^{\circ}$ 8, p. 16. 
su ortodoxia ha sido propuesta por otros autores para entender algunas imágenes de evidente carga dogmática ${ }^{52}$. En el caso de Jaca, atendiendo a la inmediatez de la reforma litúrgica y a los estrechos vínculos que unieron a Aragón con el papado, el argumento cobra aún mayor peso.

\section{Promotores, fórmulas y audiencias}

Detengámonos brevemente en las implicaciones del mensaje trinitario para los posibles mentores del programa y en el porqué de una elección tan singular como la del crismón para expresar el dogma. Respecto al primer punto, el papel desempeñado por los canónigos jaqueses en las empresas artísticas de la sede no ha recibido la atención que debiera. Éstos se han visto desplazados en cuanto a interés historiográfico por las figuras de los monarcas, obispos y nobles -mejor definidas e individualizadas en las fuentes-, o por los debates acerca de los maestros que participaron en la construcción y ornato de la catedral. Sin embargo, resulta lógico conceder una cierta responsabilidad a los miembros del cabildo jaqués como posibles ideólogos del programa escultórico llevado a la portada. ¿Quién mejor si no para manejar un bagaje textual tan rico como el que alumbró la iconografía del tímpano y de sus capiteles? San Agustín, mentor espiritual de los canónigos, destacado garante de la ortodoxia y ardiente debelador de la herejía, suponía la máxima referencia en materia trinitaria para la cristiandad occidental. Su legado teológico debió alumbrar las inquietudes dogmáticas de los responsables del programa iconográfico de Jaca ${ }^{53}$.

52 Vid. el caso silense en M. BEN-Pechat, "L'iconographie de l'Ascension dans le programme des six bas reliefs sous une lumière théologique et liturgique", El románico en Silos. IX Centenario de la consagración de la iglesia y el claustro (1088-1988), Silos, 1990, pp. 470-472, o las propias representaciones de la Trinidad esculpidas en las últimas décadas del siglo XII en E. Lozano López, Un mundo en imágenes: La portada de Santo Domingo de Soria, Madrid, 2006, pp. 70-71. Sin embargo, creemos que en el ámbito del tardorrománico esta necesidad no sería tan apremiante, habida cuenta de la consolidación de las reformas a lo largo de la primera mitad del siglo XII. Los factores que atañían a la imagen heterodoxa de la Iglesia hispana no habrían mantenido la misma vigencia casi un siglo más tarde. En este sentido se pronuncia M. Alvira: "Incorporados los Estados hispanocristianos al rito romano, ¿queda algo de la España asociada a la herejía de tiempos altomedievales? Creo que muy poco" (E. Mitre Fernández, M. Alvira Cabrer y J.E. Martínez Tur, "El debate ortodoxia-herejía y las relaciones franco-españolas en el Medievo”, E. Mitre FernÁndez, Iglesia, herejía..., op. cit., p. 187).

53 J.F. Esteban señaló la presencia de algunas expresiones localizadas en las inscripciones jaquesas en la obra agustiniana, y D. Ocón apuntó la relación de un sermón atribuido a San Agustín con algunas de las precisiones doctrinales del tímpano: J.F. EsteBAn LoRente, "Unas cuestiones...”, op. cit., p. 211; D. Ocón Alonso, "Problemática...", op. cit., pp. 253-254. El propio Agustín señala en su sermón XVII la equiparación del oso con el mal reflejada en el tímpano: ursus est diabolus. No conocemos los libros que pudieron poseer los canónigos. Sin embargo, sabemos de la existencia de dos volúmenes del De Trinitate agustiniano en el monasterio ribagorzano de Santa María de Taberna, fundado en el siglo IX. No es difícil suponer la existencia de otros ejemplares en las bibliotecas eclesiásticas aragonesas en la undécima centuria. Para la difusión de la obra agustiniana en la España medieval vid. M.C. DíAZ y DíAz, "San Agustín en la alta Edad Media española a través de sus manuscritos", Augustinus, 13 (1968), pp. 141-151; J. DivjAK, "La présence de Saint Augustin en Espagne", Coloquio sobre circulación de códices y escritos entre Europa y la Península en los siglos VIIIXIII. Actas, Santiago de Compostela, 1988, pp. 9-34. 
Precisamente la complejidad doctrinal alcanzada por el programa ha motivado que se destaque la inaccesibilidad de sus mensajes para el fiel, carente de las competencias intelectuales precisas para entender lo representado. Sin embargo, aspectos como los términos admonitorios, imperativos y vocativos de su aparato epigráfico, o la imbricación de sus imágenes en ceremonias litúrgicas de dimensión pública revelan una clara conciencia del espectador por parte de sus ideólogos. Resulta ya un tópico señalar que la recepción de los mensajes icónicos de las portadas debe entenderse en el marco de una predicación que aclarase y reforzara la doctrina ilustrada en los umbrales. Los canónigos agustinianos se caracterizaban por una vocación erudita y pastoral que concurría en un ideal de acción: la cura animarum ${ }^{54}$. En este sentido, la profusión de letreros explicativos en el tímpano y su voluntad instructiva son totalmente acordes a la dimensión pastoral de la institución canonical, y reforzarían los mecanismos mnemotécnicos que jugaban un papel esencial en el sermón y en la recepción de las imágenes. Así, un mensaje destinado en principio a una selecta elite podía obtener un mayor eco gracias al papel mediador de un clero lo suficientemente competente. Bien es cierto que la triple dimensión sacramental - penitencial, bautismal y eucarística- que caracteriza al umbral jaqués habría sido aprehendida con mayor eficacia e integridad que sus complejas disquisiciones teológicas en torno a la Trinidad, cuya audiencia primordial resultaría mucho más restringida. En virtud del intrincado juego conceptual desplegado en la portada y de los objetivos que perseguían sus imágenes y proclamas, puede afirmarse que nos encontramos ante un programa elitista, cuya trama de significados más profunda se dirigía a un espectador culto.

Si nos preguntamos por los promotores que de un modo $\mathrm{u}$ otro determinaron los mensajes del tímpano, resultan de especial interés las conexiones que pueden establecerse entre el misterio trinitario, modelo para el soberano medieval, y el ideario político de la monarquía ${ }^{55}$. No en vano, como recuerda Buesa, la catedral estuvo "llamada a ser el escenario de todas las ceremonias de la familia real" ${ }^{56}$. Las invocaciones verbales predominantes en los documentos de la cancillería regia de Aragón son de contenido trinitario (fig. 4) ${ }^{57}$. Entre las correspondientes a Sancho Ramírez y Pedro I, un número significativo de las mismas contempla la dimensión

54 J. LeClerCQ, "La spiritualité des chanoines reguliers", La vita comune..., op. cit., pp. 121-122; E. CARrero SANTAMARÍA, "Ecce quam bonum et quam iocundum habitare fratres in unum. Vidas reglar y secular en las catedrales hispanas llegado el siglo XII", Anuario de estudios medievales, 30/2 (2000), p. 787; N. JASPERT, "La reforma...", op. cit., pp. 409-410.

55 N. Quitman señala que el Liber Iudicum confiaba a la Trinidad el buen funcionamiento de la monarquía, su equilibrio y su porvenir, ideas que debieron seguir presentes en el medio hispano plenomedieval atendiendo a la vigencia del legado jurídico visigodo. Vid. N. Quitman, "La Trinité et le pouvoir royal dans les sources juridiques castillanes (XIII'-XIV è siècles)”, Mélanges de la Casa de Velázquez, XXXI (1995), p. 250.

56 D.J. Buesa Conde, “Jaca, primera capital del reino de Aragón”, J.L. Ona González y S. SÁnchez Lanaspa (coords.), Comarca de la Jacetania, Gobierno de Aragón, 2004, p. 76.

57 En el gráfico adjunto se recogen los diferentes tipos de invocación verbal según su contenido (trinitarias, cristológicas, etc.) y la presencia o ausencia de invocación monogramática asociada. Las estadísticas se han elaborado a partir de los documentos catalogados como originales en las colecciones diplomáticas editadas de los monarcas. 


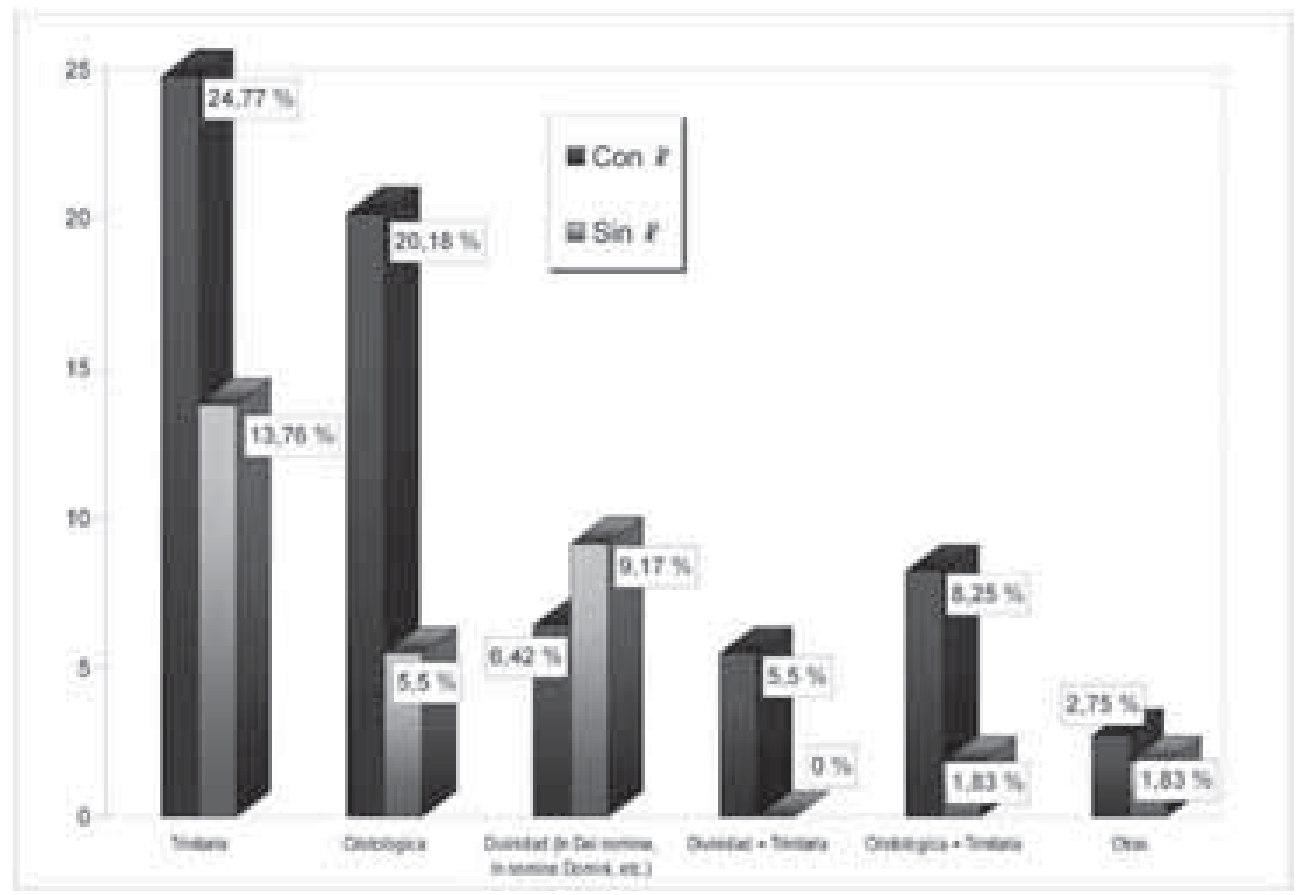

Fig. 4. Invocaciones verbales en los diplomas originales de la cancillería regia aragonesa entre los reinados de Sancho Ramírez y Alfonso II (1064-1196).

soberana de la Trinidad al aplicarle el calificativo de regnantis ${ }^{58}$. Esta mención, si bien no es exclusiva de la cancillería aragonesa, sí es reveladora de las inquietudes de la monarquía por legitimar su poder teniendo como referencia el misterio trinitario, beneficiándose por analogía de una definición común de la majestad. Algunos himnos que pudieron ser cantados en presencia del rey en el marco de ceremonias litúrgicas celebradas acaso en la propia catedral inciden en la misma idea ${ }^{59}$.

La consideración de la Trinidad como paradigma político y su incidencia en los círculos cortesanos aragoneses suman un argumento adicional a los ya señalados para explicar la proclamación del dogma en el tímpano jaqués. El misterio trinitario

58 Vid. A. Canellas López, La colección diplomática de Sancho Ramírez, Zaragoza, 1993, docs. $\mathrm{n}^{\circ} 97$ (p.

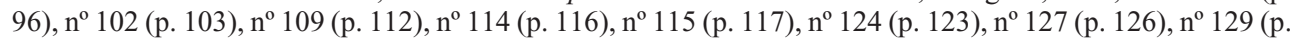
$128), \mathrm{n}^{\circ} 131$ (p. 129) y n⿳ 139 (p. 143) [incluimos tanto originales como copias]. Las fórmulas empleadas son del tipo In nomine Sancte et indiuidue Trinitatis, regnantis in secula amen; Sub Christi nomine et indiuidue Trinitatis regnantis in secula amen ( $\left.\mathrm{n}^{\circ} 129\right)$ o In nomine Sancti et indiuidue Trinitatis, Patris et Filii et Spiritus Sancti regnantis in secula amen $\left(\mathrm{n}^{\circ} 139\right)$. Seis de ellas van precedidas por el crismón, mientras que el resto presenta sólo la invocación verbal. La primacía de la invocación trinitaria frente a otras fórmulas invocativas -una constante en la cancillería del reino desde el último tercio del siglo XI- ha sido constatada en particular para el reinado de Sancho Ramírez: M.D. Cabanes Pecourt, "Diplomas y cancillería”, E. Sarasa Sánchez (coord.), Sancho Ramírez, rey de Aragón, y su tiempo (1064-1094), Huesca, 1994, pp. 35-36.

59 Vid. A. Durán, R. Moragas y J. Villarreal, Hymnarium oscense (s. XI). II. Estudios, Zaragoza, 1987, nº 1, 24. 
se plasmó en la portada del principal templo de la capital junto a otros símbolos evocadores de la institución monárquica ${ }^{60}$. El propio crismón, que fue asociado a la Trinidad en el tímpano, ha sido calificado de imprimatur real ${ }^{61}$. Como sucediera en las asambleas conciliares del mundo visigodo, la monarquía impuso su símbolo en Jaca confiriendo naturaleza de ley al dogma, cumpliendo así con la función real recogida en el Liber Iudicum y la Colección Canónica Hispana que remitía al modelo constantiniano y teodosiano ${ }^{62}$. Con la sanción del dogma, el monarca actuaba como garante de la ortodoxia, comportamiento que redundaba en su potestad soberana ${ }^{63}$.

Al hilo de las relaciones entre las últimas lecturas dadas al anagrama jaqués, la habitual presencia del crismón en la cancillería regia y su vinculación con la monarquía, cabe destacar que en uno de los anillos reales hallados en San Juan de la Peña (fig. 5) se grabó la palabra "PAX" para ser utilizada como marca sobre lacre ${ }^{64}$. Esta leyenda coincide con las letras que la inscripción del tímpano asocia a las hipóstasis divinas. La íntima conexión establecida entre el crismón y la realeza alcanzaría su máxima expresión en los diplomas ilustrados donde la figura del soberano ocupa el espacio tradicionalmente destinado al monograma ${ }^{65}$, sustituyéndolo en un ejercicio visual de Christomimesis.

La fórmula del crismón, además de conectar con la monarquía por su asociación a la autoridad regia y de contarse entre las fuentes icónicas manejadas por los $\operatorname{artistas}^{66}$, pudo ser también objeto de elección en función del celo ortodoxo que caracteriza el programa iconográfico. En efecto, el crismón ofrecía una solución al problema de la representación de la Trinidad desde presupuestos anicónicos vinculables a una tradición exegética que enfatiza la cualidad invisible del Dios Trino ${ }^{67}$.

60 Es el caso del león, significado desde la Antigüedad por su categoría regia y aclamado como soberano de las bestias y de los animales. En varias ocasiones se ha vinculado su aparición en las portadas románicas con la impartición de justicia real, como pudo ser el caso de Jaca (D.L. Simon, "A Moses capital...", op. cit., p. 218). No debemos olvidar, además, que los líderes veterotestamentarios que pueblan los capiteles de las portadas jaquesas pueden ser entendidos como arquetipos del monarca medieval (ibid. pp. 217-218).

61 D.L. Simon, "El tímpano de la catedral de Jaca", Jaca en la Corona de Aragón (siglos XII-XVIII). XV Congreso de Historia de la Corona de Aragón, III, Zaragoza, 1994, p. 419.

62 E. Mitre Fernández, Ortodoxia y herejía entre la Antigüedad y el Medievo, Madrid, 2003, p. 137; A. Rucquol, "De los reyes que no son taumaturgos: los fundamentos de la realeza en España", Rex, sapientia, nobilitas. Estudios sobre la Península Ibérica medieval, Granada, 2006, p. 26.

63 A. Rucquoi, Histoire médiévale de la Péninsule ibérique, París, 1993, pp. 13 y 361.

${ }^{64}$ C. Esco, "Conjunto de anillos del Panteón Real de San Juan de la Peña”, Signos. Arte y Cultura en el Alto Aragón Medieval, catálogo de la exposición, Huesca, 1993, p. 260; A.I. LAPEÑa PAúl, "Anillos de la necrópolis real de San Juan de la Peña", I.G. BANGo ToRviso (dir.), Sancho el Mayor y sus herederos. El linaje que europeizó los reinos hispanos, catálogo de la exposición, I, Fundación para la conservación del Patrimonio Histórico de Navarra, 2006, p. 364. Precisamente, como ha señalado Buesa, los artículos 4, 5 y 6 del fuero jaqués nos muestran al monarca como pacificador y garante de la justicia (D.J. Buesa Conde, Sancho Ramírez..., op. cit., p. 138), una "paz del rey" que podríamos poner en paralelo a la pax de Cristo del tímpano.

${ }^{65}$ M. Serrano Coll, "Imago regis. La imagen del rey de Aragón en la miniatura románica”, Románico, 9 (2009), p. 32. Así ocurre, por ejemplo, en las copias de las famosas Actas del concilio de Jaca.

66 D. Ocón Alonso, "Problemática...”, op. cit., pp. 261-262; ID., “El sello...”, op. cit., pp. 86-88.

${ }^{67}$ Hemos estudiado este aspecto en F. de A. García García, "La portada occidental de la catedral de Jaca y la cuestión de las imágenes”, F. de A. García García, I. González Hernando, E. Paulino Montero (eds.), Nuevas investigaciones en Historia del Arte. Anales de Historia del Arte, vol. extraordinario (octubre 2010), pp. 69-89. 


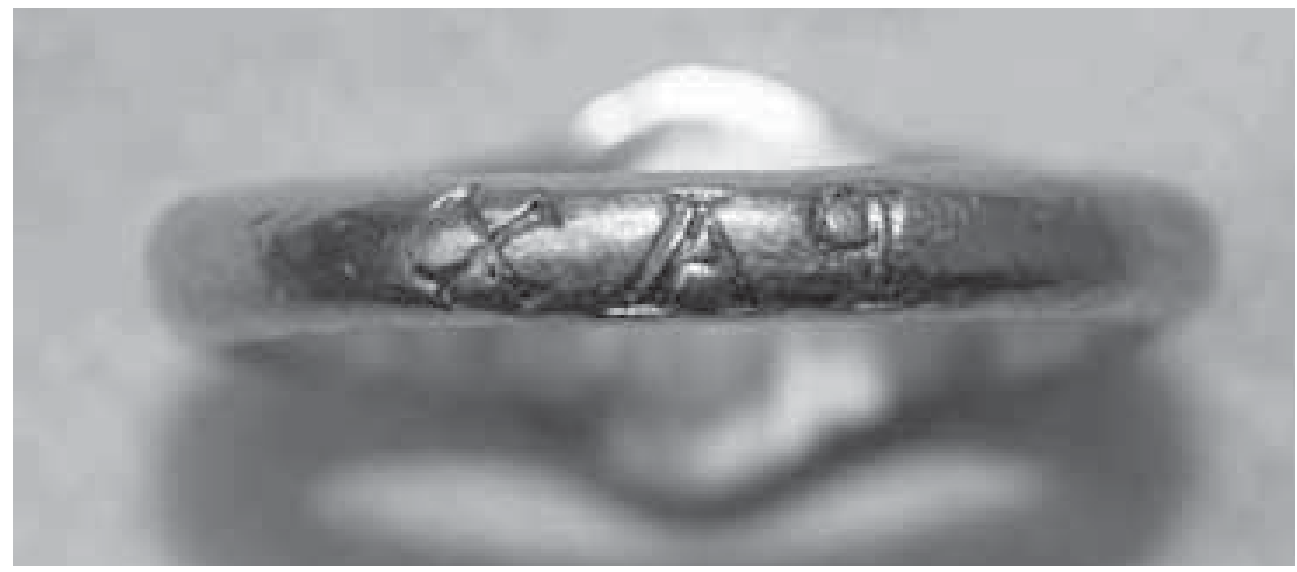

Fig. 5. Anillo procedente de la necrópolis real de San Juan de la Peña. Museo de Huesca, nº inv. 2280. Cortesía del Museo de Huesca.

La cuestión trinitaria caló profundamente en el ideario artístico de los artífices del programa catedralicio. Tal y como ha puesto de manifiesto J.F. Esteban, el proyecto arquitectónico del templo parece marcado por la referencia a la Trinidad. Esto se concreta tanto en las proporciones geométricas y ritmos empleados, articulados a partir del triángulo equilátero y las secuencias ternarias, como en el propio módulo utilizado por los constructores, el diámetro del fuste de la columna, cuya medida se reitera en el crismón del umbral ${ }^{68}$. Así pues, la fe en la Trinidad se revela como fundamento y canon del templo.

\section{La otra cara del dogma: connotaciones político-teológicas en la guerra contra el Islam}

Más allá de su respuesta a problemas inherentes al dogma cristiano, el uso del crismón como imagen central del tímpano y su asociación con la Trinidad pudieron revestir motivaciones adicionales. Es apropiado reflexionar sobre las potenciales implicaciones del tímpano en una sociedad interconfesional que integraba diversos cre$\operatorname{dos}^{69}$. Esta realidad plural influyó sin duda en la promoción y recepción del arte, pues preocupaba a las elites eclesiásticas y civiles responsables de las empresas monumentales. La divisa trinitaria del tímpano actuaría en dos niveles: como se ha señalado, el crismón evocaba la victoria cristiana sobre el paganismo actualizando su simbología en el marco de las campañas contra el Islam en las que Aragón se hallaba implicado ${ }^{70}$;

68 J.F. Esteban LoRente, “La metrología...”, op. cit., pp. 241 y 250-251.

${ }_{69}$ Aspecto abordado recientemente por Janice Mann en lo concerniente a la recepción de sus imágenes. Vid. J.E. Mann, Romanesque Architecture..., op. cit., pp. 149-154.

70 D. Ocón Alonso, "Problemática...", op. cit., p. 260; R. BARTAL, "The survival of early christian symbols in $12^{\text {th }}$ Century Spain”, Principe de Viana, XLVIII, 181 (1987), pp. 299-315. 
a su vez, presidía la portada del principal templo de una ciudad en la que convivían diversos credos para los que la Trinidad suponía una diferencia doctrinal insalvable ${ }^{71}$. El radical monoteísmo de musulmanes y judíos rechazaba cualquier dimensión trinitaria de Dios ${ }^{72}$. Por motivos análogos, a ojos de las otras dos grandes religiones del Libro resultaba inadmisible el hecho de que Cristo fuera engendrado por Dios (Padre) y compartiera con Él una misma naturaleza divina. Esta posición divergente en torno a dos de los principales puntos de la fe adquirió un prominente lugar en la controversia religiosa ibérica y en la literatura apologética desde el siglo $\mathrm{XI}^{73}$. Buena prueba de ello puede encontrarse, entre otros ejemplos, en la obra de Ibn Hazm (994-1064) y en la recepción de la Apología de al-Kindi por parte cristiana ${ }^{74}$. Las acusaciones de "politeístas" y "trinitarios" contra los cristianos aparecen continuamente en las fuentes islámicas ${ }^{75}$. Por lo tanto, exponer públicamente las diferencias religiosas contribuía significativamente a reafirmar el carácter ortodoxo del programa y de sus ideólogos ${ }^{76}$. En el tímpano de Jaca se expresó la lucha contra el Islam en su doble vertiente, militar y apologética, y por ello la Trinidad fue asociada a un símbolo de claro sabor bélico como el monograma constantiniano.

La alteridad religiosa fue concebida frecuentemente en la España medieval en términos de "paganismo" y de "herejía"77. El poder político se sirvió de ello

71 Lacarra señala la presencia de judíos y musulmanes en Jaca con anterioridad a la concesión del fuero. Vid. J.M. LACARRA, "Desarrollo urbano de Jaca en la Edad Media", Estudios de Edad Media de la Corona de Aragón, IV (1951), p. 146. Su artículo n 23 menciona a sarracenos en régimen servil dentro de la ciudad. La existencia de judíos se plasma por primera vez en documentos de compraventa de mediados del siglo XI (M.A. Motis Dolader, "Los judíos jacetanos en la Edad Media”, J.L. Ona González y S. SÁnchez Lanaspa (coords.), Comarca..., op. cit., p. 89).

72 M. DE EPAlza Ferrer, Jesús entre judios, cristianos y musulmanes hispanos (siglos VI-XVII), Granada, 1999 , p. 270.

73 Aunque desborden el marco cronológico y geográfico que centra nuestro trabajo, obras como las de T.E. Burman, Religious polemic and the intellectual history of the mozarabs, c. 1050-1200, Leiden-Nueva York-Colonia, 1994, y D. Thomas, Christian Doctrines in Islamic Theology, Leiden-Boston, 2008, nos aproximan a la literatura polémica producida en ambas confesiones a propósito de a la cuestión trinitaria.

74 A. Ljamai, Ibn Hazm et la polémique islamo-chrétienne dans l'histoire de l'islam, Leiden, 2003, pp. 89-103; F. GonzÁlez MuÑoz, "La versión latina de la 'Apología de al-Kindi’ y su tradición textual”, M. BARceló, P. Bádenas de la Peña y J. Martínez Gázquez (coords.), Musulmanes y cristianos en Hispania durante las conquistas de los siglos XII y XIII, Barcelona, 2005, pp. 25-40.

75 E. Lapiedra Gutiérrez, Cómo los musulmanes llamaban a los cristianos hispánicos, Alicante, 1997, pp. $158-175$ y $332-334$.

${ }^{76}$ Un interesantísimo paralelo para este proceder, desde el bando confesional contrario, es el ofrecido por las inscripciones coránicas dispuestas en las puertas del muro de qibla de la aljama cordobesa. Dicho programa epigráfico presenta una refutación del dogma cristiano de la Trinidad articulada en torno a la cuestión de la naturaleza divina de Cristo en cuanto engendrado por el Padre. Vid. S. Calvo Capilla, "Justicia, misericordia y cristianismo: una relectura de las inscripciones coránicas de la Mezquita de Córdoba en el siglo X", Al-Qantara, XXXI/1 (2010), pp. 165-178.

77 E. Mitre FernÁndez, "Otras religiones ¿otras herejías? (El mundo mediterráneo ante el 'choque de civilizaciones’ en el Medievo)”, En la España Medieval, 25 (2002), pp. 24-40 y 44-45; ID., “Otras religiones ¿otras herejías? (Los judíos en el Medievo europeo y el especial caso hispánico)”, Hispania Sacra, LIV, 110 (2002), pp. 515-552. 
para justificar la confrontación bélica y como mecanismo de legitimación. Así, y en relación con lo anteriormente expuesto, cabe señalar que la imagen heterodoxa que podía ofrecer el mundo hispánico a ojos de la teocracia papal se veía también influida por la presencia islámica en la Península ${ }^{78}$. Gregorio VII situaba al Islam al mismo nivel que otras herejías hispanas al reclamar la aceptación de la liturgia romana, y destacaba en sus misivas el peso de la invasión musulmana en el olvido del antiguo vínculo que había unido a España con la Santa Sede ${ }^{79}$. La contienda bélica que mantuvieron Sancho Ramírez y sus sucesores frente al Islam se vio reforzada por un posicionamiento simultáneo a nivel ideológico en el que el papado desempeñó un papel esencial, evidenciando su creciente influjo en los asuntos eclesiásticos y políticos de Aragón ${ }^{80}$. La actuación de los monarcas en el sometimiento del infiel realzaba, ante todo, su condición de milites Sancti Petri, cumpliendo los designios papales de orientar el ideal hispano de cruzada al combate contra el islam andalusí.

En conclusión, el mensaje dogmático del tímpano no sólo reafirmaba un principio básico de la fe cristiana, sino que podía entenderse también en términos de propaganda contra el "otro" religioso. Este procedimiento discursivo está presente en tratados teológicos contemporáneos como Cur Deus Homo de San Anselmo, donde no sólo se contempla el alcance que las doctrinas expuestas pueden tener para una audiencia cristiana, sino también para judíos y musulmanes, concebidos como receptores potenciales ${ }^{81}$. El papel de la escultura jaquesa en este engranaje ideológico supone un campo de estudio poco explorado hasta el momento. Éste reviste, además, connotaciones de tipo litúrgico que pueden perfilar los mecanismos de asimilación del lábaro como imagen propagandística en el Aragón de finales del siglo XI, aspecto sobre el que esperamos volver en ocasiones posteriores.

78 Señala M. Alvira que "a partir del siglo VIII, la imagen de una España diferente (valga el viejo tópico) viene dada, sobre todo, por el hecho de la prolongada presencia islámica” (E. Mitre FernÁNDEZ, M. AlvirA CAbrer y J.E. Martínez Tur, "El debate...”, op. cit., p. 185). En el mundo franco se llegó a insinuar que la contaminación herética de la liturgia hispana tuvo como castigo la invasión musulmana (E. Mitre FERNÁNDEZ, Iglesia, herejía..., op. cit., pp. 54-55). Heterodoxia cristiana e Islam aparecen conectados en algunas relecturas de la doctrina adopcionista: M. RiU y RiU, "Revisión del problema adopcionista en la diócesis de Urgel", Anuario de Estudios Medievales, 1 (1964), p. 82; M. de Epalza Ferrer, "Influences islamiques dans la théologie chrétienne médiévale: l'adoptianisme espagnol (VIII ${ }^{m e}$ siècle)”, Islamochristiana, 18 (1992), pp. 55-72; ID., "Félix de Urgel: influencias islámicas encubiertas de judaísmo y los mozárabes del siglo VIII", Acta historica et archaeologica medievalia, 22/2 (1999-2001), pp. 31-60.

79 B. Llorca, "Derechos...", op. cit., p. 560; T. Deswarte, "Une chrétienté hérétique...”, op. cit., p. 182.

80 L. García-Guijarro Ramos, "El Papado...", op. cit., pp. 248-249. Como señala C. de Ayala, "por un lado, la reforma en su doble objetivo -restablecimiento de la unidad e imposición de disciplina- y, por otro, la reconquista cristiana, aparecen como dos aspectos inseparables de un mismo programa de actuación pontificia” (C. de Ayala Martínez, Sacerdocio y reino en la España altomedieval. Iglesia y poder político en el Occidente peninsular, siglos VII-XII, Madrid, 2008, p. 307).

81 R. Roques, "Introduction”, op. cit., pp. 71-73 y 84; M. DE Epalza Ferrer, "Corrents islàmics aparents i amagats a la cultura catalana medieval”, Estudi General, 9 (1989), pp. 111-113. 


\section{Consideraciones cronológicas}

El momento pertinente en el que la portada jaquesa pudo ser concebida y realizada es un aspecto insoslayable en su estudio iconográfico, si bien somos conscientes de que las lagunas documentales no favorecen al investigador. Nos corresponde valorar qué cronología resulta acorde a los aspectos reseñados en los apartados precedentes. Una vez que Moralejo refrendó con argumentos histórico-artísticos las precisiones documentales realizadas por Ubieto, se llegó a un relativo consenso de ubicar las labores escultóricas catedralicias a partir de la década de 1080. De este modo, el arco temporal definido por los últimos años del reinado de Sancho Ramírez y el reinado de Pedro I constituye el marco cronológico de referencia ${ }^{82}$. Evidencias como el modillón de estirpe tolosana emplazado en el ábside mayor del templo o la imitación de soluciones jaquesas en Sasave abogan por una cronología avanzada en la década de $1090^{83}$, mientras que otros argumentos, como el impacto de la plástica catedralicia en Ujué, apuntan a fechas algo anteriores ${ }^{84}$. Recientemente, F. Prado-Vilar y M. Castiñeiras han coincidido en atribuir a la escultura jaquesa una cronología en torno a la última década del siglo XI, con propuestas divergentes en lo que respecta a la trayectoria de sus artífices ${ }^{85}$.

Uno de los problemas de mayor calado a la hora de asignar fechas a la portada reside en armonizar su discurso teológico-político con las circunstancias internas y externas del reino aragonés. Si tomamos como referencia el episcopado de García (1076-1086) parecería lógico vincular el programa con la promoción regia y con la presencia de un miembro de la casa real al frente de la sede ${ }^{86}$. Sin embargo, desde 1080, y especialmente desde 1082-1083, las relaciones entre éste y Sancho Ramírez se caracterizaron por una enconada enemistad ${ }^{87}$. García, pese a su celo reformador en las costumbres y vida del clero, se significó por una férrea oposición al vínculo con el papado ${ }^{88}$. Durán Gudiol afirma que desde 1080 hasta el reinado de Alfonso I el obispado de Jaca no contó con un especial favor regio por las desavenencias de los

82 Vid. un estado de la cuestión en D. Ocón Alonso, "El sello...", op. cit., p. 78, n. 3.

83 S. Moralejo Álvarez, "Une sculpture du style de Bernard Gilduin à Jaca", Bulletin Monumental, CXXXI (1973), pp. 7-16; D.L. Simon, "San Adrian de Sasave and sculpture in Altoaragón”, N. STRATFORD (ed.), Romanesque and Gothic: Essays for George Zarnecki, Woodbridge, 1987, pp. 179-184.

84 J. Martínez de Aguirre, "El siglo XI", C. Fernández Ladreda (dir.), El arte románico en Navarra, Pamplona, 2004 (2002), pp. 74-77, y p. 82, n. 50.

85 M.A. CastiÑEIras González, "Verso Santiago?...”, op. cit., pp. 387-388; F. Prado-Vilar, "Saevum...”, op. cit., p. 185, la data c. 1093-1094.

${ }^{86} \mathrm{Tal}$ es la cronología propuesta por S.H. CALDwELL "Penance, Baptism, Apocalypse: The Easter context of Jaca Cathedral's west tympanum", Art History, III/1 (1980), pp. 25-40.

87 A. Durán Gudiol, La Iglesia..., op. cit., pp. 44-47; A.I. Lapeña Paúl, "Iglesia y monacato en el reinado de Sancho Ramírez", E. Sarasa Sánchez (coord.), Sancho Ramírez..., op. cit., p. 143.

88 L. García-Guijarro Ramos, "El Papado...”, op. cit., pp. 257-258. García Ramírez se oponía a la directa dependencia de Roma de los principales establecimientos eclesiásticos del reino al mermar considerablemente su poder episcopal. 
monarcas aragoneses con sus mitrados ${ }^{89}$. Este panorama debe ser, no obstante, matizado en lo concerniente al desarrollo de las labores constructivas y ornamentales del templo. Es difícil calibrar en qué medida la actividad artística de la sede pudo verse afectada por tales disensiones. Ahora bien, la catedral de Jaca suponía la máxima expresión de la identidad del reino en términos edilicios y plásticos que podía hallarse en la capital. Su construcción y proyecto ornamental no pueden entenderse sin el concurso de la promoción regia, pese a las diferencias que el monarca pudiera mantener con ciertas elites eclesiásticas. De hecho, la catedral no vio siquiera interrumpida su actividad artística en los años posteriores a la conquista de Huesca (1096), momento en el que Jaca fue desposeída de su capitalidad y los intereses de la monarquía se dirigieron hacia las regiones meridionales ${ }^{90}$. Los ingresos reales en concepto de multas y parias, así como las rentas del peaje del rey, siguieron nutriendo las arcas jaquesas ${ }^{91}$.

Un momento propicio para la confección del programa de la portada puede situarse en el entorno de 1088-1090, años en los que confluyen una serie de factores ideológicos y circunstancias históricas que podrían explicar algunas de las singularidades iconográficas del tímpano. Quizá el hecho más determinante sea la recuperación de las buenas relaciones con la Santa Sede tras la infeudación de Aragón en 1088-1089². El pleno restablecimiento de la alianza con el Papa bien podría haber merecido una conmemoración plástica en el tímpano aragonés. La lucha contra el Islam y la propaganda regia, con la campaña de Huesca como objetivo próximo, conocieron entonces uno de sus momentos álgidos ${ }^{93}$. En 1088 había ascendido al solio pontificio Urbano II, quien además de anunciar años más tarde la cruzada a los Santos Lugares (1095) apoyó decididamente la particular cruzada hispana contra el Islam peninsular. Y, como hemos visto, tanto la vinculación con Roma como la lucha contra el infiel resultan clave para comprender el mensaje consignado en el crismón jaqués y su dimensión trinitaria.

También reviste gran interés comprobar cómo en torno a esos mismos años se concentra en la documentación la mayor parte de invocaciones que incluyen la cláusula regnantis aplicada a la Trinidad ${ }^{94}$. Este detalle, aparentemente formulario, puede ser revelador de determinadas actitudes y concepciones presentes entre los mentores del programa iconográfico ${ }^{95}$. En otro orden de asuntos, la sede de Jaca perdió a su

89 A. Durán Gudiol, Aragón, de condado a reino, Zaragoza, 1985, p. 126.

90 El desplazamiento de intereses que conllevó la toma de Huesca, con el traslado del propio obispo, ya fue señalado por Moralejo como un escollo difícil de salvar a la hora de retrasar en exceso las labores escultóricas de la catedral. Merece ser tenida en consideración, no obstante, la opinión de D. Simon, quien ve en el tímpano un manifiesto del prestigioso pasado de la antigua sede episcopal y capital del reino realizado en un momento en el que Jaca vio mermado su peso específico dentro de Aragón (D.L. Simon, “El tímpano...”, op. cit., p. 418).

91 C. Laliena Corbera, Pedro I de Aragón y de Navarra (1094-1104), Burgos, 2000, p. 215.

92 Vid. el texto de la carta remitida por Sancho Ramírez a Urbano II y la respuesta del pontífice en P. KEHR, “Cómo y cuándo...", op. cit., p. 319-321.

93 Entre 1088-1089 se construyó el castillo de Montearagón con vistas a este decisivo asalto.

94 Hasta diez invocaciones del tipo apuntado se contabilizan entre los años 1087-1093.

95 Amancio Isla ha señalado cómo un estudio de las variantes presentes en las invocaciones y otras fór- 
obispo García Ramírez en 1086, y el legado Frotardo de Thomières -ejecutor de los designios papales y merecedor de la confianza del monarca- consagró en 1087 a su sucesor Pedro, considerado de origen pinatense. De ser cierta tal proveniencia, podría ser un indicio más que apuntase a las fechas propuestas. No en vano dicho cenobio ha sido señalado por varios autores como un centro intelectual de referencia para la iconografía del tímpano, tanto por su ambiente teológic ${ }^{96}$ como por las invocaciones y grafías de los crismones presentes en sus documentos ${ }^{97}$.

Realizadas estas precisiones, y ateniéndonos a los factores de orden ideológico que confluyeron en el diseño del tímpano, debemos reconocer que los planteamientos de su programa iconográfico habrían conocido una óptima recepción en tiempos de Pedro I (1094-1104). Las buenas relaciones con el papado, la política de reforma religiosa y la oposición bélica e ideológica al Islam no perdieron vigencia a la muerte de Sancho Ramírez. Los estrechos contactos mantenidos entre Pedro I y Urbano II en la segunda mitad de la década de $1090^{98}$, o la convocatoria del concilio reunido en Bari en 1098 para clarificar las posiciones teológicas en torno al Espíritu Santo, actualizarían los mensajes del tímpano jaqués en los años siguientes a su realización. Aun en el caso de que la ejecución material o el montaje de la portada correspondiesen a estas fechas más tardías, podemos afirmar que su programa ha de entenderse en relación con las coordenadas ideológicas establecidas en el reinado de Sancho Ramírez, cuyas líneas de actuación tuvieron un fiel valedor en su sucesor. Dicha continuidad es manifestada en varios documentos enviados por Pedro I a Urbano II en los que continuamente recuerda la figura de su padre, como es el caso de un memorial de 1095 que comienza asegurando la fidelidad personal del monarca hacia Roma en la memoria de Sancho Ramírez ${ }^{99}$.

mulas utilizadas en los diplomas arroja luz sobre las inquietudes y la mentalidad de un determinado momento histórico: A. Isla Frez, "Cosmovisión (religión y cultura) en la cristiandad hispana: desarrollos de la piedad en torno al año mil", J.I. DE LA IgLEsia DuarTe (coord.), Cristiandad e Islam en la Edad Media hispana. XVIII Semana de Estudios Medievales, Logroño, 2008, pp. 84-85.

96 D. Ocón Alonso, "Problemática...", op. cit., p. 252, n. 30.

97 J.F. Esteban LoRente, “Las inscripciones...”, op. cit., pp. 157-158; ID., “El tímpano...”, op. cit., pp. 461 y 467. Sin embargo, hemos de señalar que el obispo Pedro caería en desgracia por defender los intereses de su sede ante la inminente toma de Huesca (A. Durán Gudiol, Aragón, de condado..., op. cit., p. 126). Reiteramos por ello que el complejo panorama institucional del momento dificulta el hallazgo de una cronología certera.

98 Recordemos, por ejemplo, la carta enviada por el papa el 16 de marzo de 1095 en la que confirma a Pedro I y su reino "bajo la tutela y dilección de la sede apostólica" (D. MAnsilla, La documentación..., op. cit., doc. $\mathrm{n}^{\mathrm{o}}$ 34, pp. 53-54). En 1097 Urbano II lo felicita por sus actuaciones hasta la fecha en una misiva donde lo insta a colaborar en la construcción de una nueva catedral para Pamplona. Sobre las relaciones de Pedro I con el papado vid. C. Laliena Corbera, Pedro I..., op. cit., pp. 180-186.

99 Hoc autem totum Sancius rex, uester humillimus et obediens filius, in uita sua habere bonitatis uestre respectu promeruit, modo autem eius animam orationum absolutionisque uestre subsidio adiutam oppido esse non diffidimus. Cuius ergo sequens auctoritatem, in omnibus bonis Deo iunante paterne tradicionis emulator bonus esse desiderans, me ipsum dominatui uestro subdidi et nullum alium dominum excepto Deo sanctisque eius habere elegi eadem ductus qua etiam pater intentione (reproducido por P. KEHR, "El papado...", op. cit., p. 181). En términos semejantes se pronuncia Pedro I en una carta del año 1098 mediante la que remite al Papa el tributo acordado de 500 mancusos: ibid., p. 185. El propio pontífice recuerda enfáticamente la figura de Sancho Ramírez en la carta a Pedro I de 1095 citada en la nota anterior. 


\section{Conclusión}

En un contexto como el aragonés del tránsito hacia la duodécima centuria, el umbral de Jaca supuso un excepcional espacio para la afirmación de identidades y un reflejo de las mutaciones y herencias culturales, eclesiásticas y políticas del emergente reino de Aragón. Su tímpano celebraba el nuevo status resultante de la alianza con Roma y constituía un manifiesto de acción política y religiosa contra el Islam, definiendo visualmente las directrices ideológicas de sus patronos. El dogma de la Trinidad se convirtió en el recurso más apropiado para expresar estos conceptos y supuso un punto de compromiso entre la tradición hispana y la dimensión alcanzada por Aragón en el contexto europeo. 